\title{
Proposed Marketing Communication Strategy to Increase Buyer's Decision to Buy House (Case Study: PT. Sedulur Guyub Rukun)
}

\author{
Radityo Chrisna Adi ${ }^{1}$ and Sonny Rustiadi ${ }^{1}$
}

\begin{abstract}
PT. Sedulur Guyub Rukun is a property developer with the main business as a housing developer with premiumclass products in Jombang, East Java. the house residence name is Jombang Citra Raya. In recent year, the company faced the decreases in sales as a business problem and this research examine the business issue and solve the issue with the proposed business strategy. The research uses several analytic tools such as internal analysis uses STP, Marketing Mix analysis and Indepth interview, for external analysis uses Five Porter's forces, Competitor analysis questionnaire with multiple linear regression model. The analytic tools are used to formulate business solution that able to increase customers purchasing decision to buy a house and increase the brand awareness of the company by using a marketing communication strategy. From 100 respondents are used as the sample for the questionnaire, the result finds the most significant factor to influence the buyer's decision is Products and the least factors are Prices. This research result becomes the reference to build Integrated Marketing Communication (IMC) that consists of advertising, publicity and sales promotion as marketing communication media for the IMC strategy. To implement it, the schedule plan and budget allocation for IMC is proposed.
\end{abstract}

Keywords-Marketing Mix, Purchase Decision, STP, Five Porter's Forces, Multiple Linear Regression.

\section{INTRODUCTION}

\section{A. Business Background}

Indonesia is a developing country that has experienced an increase in the economy and population growth, this also contributes to the growth and development of the industrial business sector, residential and commercial infrastructure and property which is widely used as a business opportunity by the government or the private sector. One of the indicators for economic growth is GDP, for the year 2015-2018 GDP per capita increasing for approx. $5 \%$ each year and it indicates Indonesia in good economic growth [1], and also GDP per capita is one indicator to determine the prosperity of a region. The greater the income obtained from the region the more prosperous for the region. For residential and commercial property markets. The property market is very growing in developing cities or districts. The total population in

\footnotetext{
${ }^{1}$ Radityo Chrisna Adi and Sonny Rustiadi are with School of Business and Management, Institut Teknologi Bandung, Indonesia. Email: Radityochrisna13@gmail.com.
}

Indonesia is 265 million [1] and for east java, the population increasing from 39,1 million in 2016 to 39,9 million in 2018 [1] and reach the regional GDP per capita Rp.47.960.000 in 2018. From this population growth and GDP per capita growth in indicates the government's ability to develop and encourage the national economy on regional development can still move in a positive direction and government policies regarding economic development greatly affect the growth of economic in each province in Indonesia, and this affect to the growth of property industry. One of the biggest factors of Property growth is the number of population increases and East java populations experienced a significant increase the population of east java caused the increases the demand of property especially housing and the government issued a property backlog number as indicator used by the government to measure the number of housing needs in Indonesia, from 2014-2016 in East Java the property backlog is increasing from 468.361 to 993.020 in 2019[2]. And it concludes that the property industry opportunity in East Java is very interesting for property/real estate company.

\section{B. Business Issue}

PT. Sedulur Guyub Rukun and Jombang Citra Raya Housing have been established in 2009, from the journey of land acquisition and preparation for the land preparation to build a housing has become a long journey, until 20102011 several housing units and shophouses were built as the success of the first sale, up to in 2018, total sales have reached $45 \%$ of the total lots/houses provided for sale. The company suffered the downward trend in home sales occurred in the last 2 years (2016-2018) and caused a financial loss because the company does not achieve the sales target so that the company was deemed necessary to change the company's strategy and evaluate overall performance for the good of the company in the future. One of the other problems is PT. Sedulur Guyub Rukun does not have sufficient marketing strategy and it is caused the company to get difficulties to sell the products and also the low brand awareness and recognition that makes the company have difficulty competing in the market. 


\section{Research Objectives}

To solve the existing problem, PT. Sedulur Guyub Rukun determined the objectives to achieve the solution for the problem.

- To find and propose the right marketing strategy for Jombang Citra Raya Housing

- To identify the causes of decreases of Housing sales in Jombang.

- To find and propose the potential advantages from customer needs for making new business strategy to affect sales of housing of Jombang Citra Raya.

\section{Research Limitation}

This Research Limitation is only limited to exploring a marketing problem that causes decreases of house sales in Jombang Citra Raya and find the best marketing communication strategy to increases the house sales and value of Jombang Citra Raya. The result of implementation and maintain of marketing strategy is not covered by this research.

\section{LITERATURE REVIEW}

\section{A. Market Competition}

To measure the competition in the property market, A specific marketing tool is needed to understand and measure the competition level and to know the positioning of PT. Sedulur Guyub Rukun. the analysis tool that will be used is Five Porter's Force and competitor analysis. Five Porter's Force theory by Porter mentioned the importance of knowing the company's competitiveness. Five Porter's Force is founded by Michael E. Porter, Porter's Five Forces is a model that identifies and analyzes five competitive forces that shape every industry, and helps determine an industry's weaknesses and strengths. Frequently used to identify an industry's structure to determine corporate strategy, Porter's model can be applied to any segment of the economy to search for profitability and attractiveness [3]. And also Five Porter's force is analytic tool is useful for a company strategist who understands that competition extends well beyond or existing rivals will detect wider competitive threats and be better equipped to address them [4].

\section{B. Market Segmentation, Targeting and Positioning}

To know the position of the company in the market, STP (Segmenting, Targeting, and Positioning) analysis is the appropriate tool for it. Market segmentation is the process of dividing a market into smaller segments of buyers with distinct needs, characteristics, or behaviors that might require separate marketing strategies or mixes [5]. To be more focused, the company must arrange the target market that suit with the price of the product. market Targeting is evaluating the market segment's attractiveness and selecting one or more segments to enter [5]. Based on the segmentation statement and defining the market segment, the company evaluates and identifies the market segment and targeting the right market according to the product. Targeting is useful for a company to be more concentrated in finding the right costumers for their product. Next step, the company must arrange the most suitable facility or value offers according to the product's price. the step is the Positioning is arranging a product or service to occupy a clear, distinctive and desirable place relative to competing for product or service in the minds of the target market [5]. Kotler and Armstrong stated that the positioning strategy can be determined by value proposition. The value proposition by Armstrong and Kotler determined the connection between benefits and price and mentioned into 5 definitions: more for more, more for the same, more for less, the same for less, less for much less [5].

\section{Marketing Mix (4P)}

According to Kotler, Marketing Mix is the set of controllable variables that the firm can use to influence the buyer's responses. The marketing mix is the set of marketing tools that the firm uses to pursue its marketing objectives in the target market [5]. marketing mix is used to know product offers to the market for attention, acquisition, use, consumption that might satisfy a want or need because the product is a key element in the overall market offering. Marketing mix analysis will useful to know the company's internal condition and strategy for the market condition and opportunity and marketing mix involves many crucial decisions relating to each element of the mix. The impact of the mix will be the consideration for each element and they are integrated so that the combined effect leads to the best results. Based on Kotler, Product means the goods-and-services combination the company offers to the target market, Price is the amount of money customers must pay to obtain the product, Place includes company activities that make the product available to target consumers, and promotion refers to activities that communicate the merits of the product and persuade target customers to buy it.

\section{METHODOLOGY}

\section{A. Conceptual Framework}

To explain the steps in research and apply them to research, conceptual framework is needed as a tool to make research findings structured better and more meaningful. Within the right research framework, it will be able to find the most suitable marketing communication strategy that can solve problems at PT. Sedulur Guyub Rukun.

\section{B. Method of Data Collection and Analysis}

To find the root cause of the problem and make a solution for the problem in PT. Sedulur Guyub Rukun, This Research will use both quantitative and qualitative research, Quantitative Research is used to quantify the problem by way of generating numerical data or data that can be transformed into usable statistics. Qualitative 
research is used to quantify attitudes, opinions, behaviors, and other defined variables - and generalize results from a larger sample population. Quantitative research uses measurable data and formulate facts and patterns in the research, this research is divided into 2 strategies for conducting quantitative and qualitative research ; first strategies is confirmatory research as a quantitative method, in which researchers formulate hypotheses on the basis of the previous research and test them against empirical data and the second is Exploratory research, is by definition exploration, a kind of exploration into the data. This method starts with the gathered data and exploring to formulate hypotheses and theories based on the understanding derived from the data. Exploratory research as a qualitative method in this research.

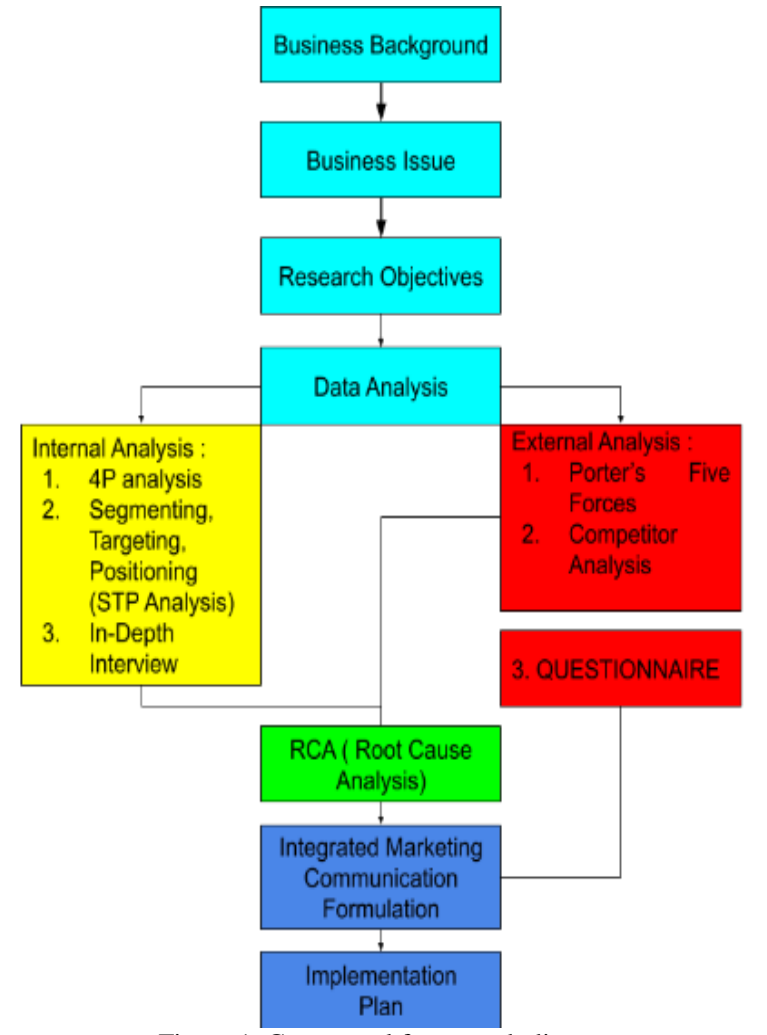

Figure 1. Conceptual framework diagram

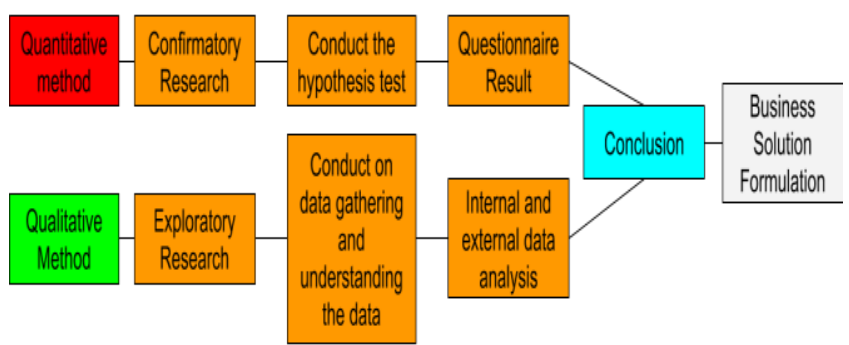

Figure 2. Research methodology diagram

This research will use literature studies, management analytic tool, interview, questionnaire and data analysis to for internal analysis, this research uses analytical tools:
Marketing mix (4P), Five Porter's Forces to find the internal condition of the company uses theoretical business tool and In-depth interview with CEO and Marketing admin to find the real problem, existing strategy and business plan in the company that caused the decreases of sales. For external analysis, this research uses analytical tools : Five Porter's Forces and Competitor analysis to find the external condition that controls the business strategy and progress of this company in competing in this business sector. The questionnaire are used to find the factors that determine the buyer in buying a house and make a summary of all analysis of the most significant factor in respondents that drives their purchase decision.

\section{RESUlt AND DisCUSSION}

\section{A. Internal factor analysis : Marketing Mix (4P)}

The Main Product of Jombang Citra Raya is houses, there are consists many of house type: there are consists of 6 house type by their building area; type 36 , type 45 , type 54 , type 61 , type 75 . Product prices from PT. Sedulur Guyub Rukun depends on the size of the units available, the area of land and the economic conditions of the company and macroeconomics (Inflation, Policy etc.). The cheapest price for a house is $234,500,000$ and the most expensive is $544,800,000$. The location of Jombang Citra Raya located in Jombang, located in residential area and near to city centre with a distance of approximately $3 \mathrm{~km}$ to city centre and in close proximity to residental location there are train station and bus stop. This gives advantages as the main competence of this housing regency. The current promotion channel of Jombang Citra Raya is still conventional promotion method, Jombang Citra Raya promotes its product by banner and printed advertising and using organic ways to gain customers. other promotions is by online marketplace and online news media to promote and give reviews about the company's product.

\section{B. Internal factor analysis: STP (Segmenting, Targeting, Positioning)}

PT. Sedulur Guyub Rukun must segmenting the ideal customers for their product for necessity of marketing strategy to keep focused on. Based on data analysis and exploration, PT. Sedulur Guyub Rukun has determined the segmentation based on geographic, demographic, psychographic and behavioral. Table 1 is STP explanation. And the last is positioning on STP analysis, Positioning is arranging a product or service to occupy a clear, distinctive and desirable place relative to competing product or service in the minds of target market [5]. Positioning for the company based on their value proposition between benefit and price. the suitable positioning for the company is more for the more, which is the greater the cost incurred to get the product, the more benefit obtained by customer are getting bigger. Table 2 is positioning table of PT. Sedulur Guyub Rukun. 
TABLE 1.

STP TABLE

\begin{tabular}{lll}
\hline \hline & Segmenting & Targeting \\
\hline Geographic & Customer from Jombang, Mojokerto, Kertosono, Nganjuk, Kediri and Surabaya & Customer from Jombang and Surabaya \\
& Customer with age below 17 y.o until above 64 y.o & Customer with age from 25-64 y.o and 64-75 y.o \\
Demographic & with total income of Rp.2.500.000 to above Rp.10.000.000. & With total income of Rp.6.000.000-10.000.000 \\
Psychographic & Social class from Middle low to Upper class & Social class from Middle Up to Upper class \\
\hline \hline
\end{tabular}

TABLE 2.

POSITIONING TABLE

\begin{tabular}{cccc}
\hline \multirow{2}{*}{ The Benefit } & \multicolumn{3}{c}{ The Price } \\
\cline { 2 - 4 } & More & The same & The Less \\
\hline More & More for the More & More for the same & More for less \\
The Same & More for the Same & same for the same & same for less \\
The Less & more of the less & Same for the same & Less for much less \\
\hline \hline
\end{tabular}

TABLE 3.

FIVE PORTER'S FORCES

\begin{tabular}{|c|c|c|c|c|}
\hline Porter's Force & Factor & Ranking & \multicolumn{2}{|c|}{$\begin{array}{lll}\text { Reason } \\
\end{array}$} \\
\hline \multirow{3}{*}{$\begin{array}{l}\text { Bargaining } \\
\text { of buyer }\end{array}$} & \multirow{2}{*}{$\begin{array}{l}\text { Number of Customers } \\
\text { Cost of Changing }\end{array}$} & High & \multirow{3}{*}{\multicolumn{2}{|c|}{$\begin{array}{l}\text { The bargaining power of buyer is high, because buyer is in total control with } \\
\text { their purchase decision }\end{array}$}} \\
\hline & & High & & \\
\hline & Price Sensitivity & High & & \\
\hline \multirow{2}{*}{$\begin{array}{l}\text { Bargaining power } \\
\text { of supply. }\end{array}$} & \multirow{2}{*}{$\begin{array}{l}\text { many suppliers with same material } \\
\text { Able to Substitute }\end{array}$} & Low & \multirow{2}{*}{\multicolumn{2}{|c|}{$\begin{array}{l}\text { Because there are many suppliers that can support the business with similar } \\
\text { product/material }\end{array}$}} \\
\hline & & Low & & \\
\hline $\begin{array}{l}\text { Threat of New } \\
\text { Entrants }\end{array}$ & Time cost of entry & Low & \multicolumn{2}{|c|}{$\begin{array}{l}\text { Because of time and cost of entry are high and to compete in this industry } \\
\text { need a company with high expenditure capital and proper resources }\end{array}$} \\
\hline \multirow[t]{2}{*}{$\begin{array}{l}\text { Threat of Substitute } \\
\text { products or Services }\end{array}$} & $\begin{array}{l}\text { Existing House currently on sale/ } \\
\text { second hand house }\end{array}$ & High & \multicolumn{2}{|c|}{$\begin{array}{l}\text { Secondhand house and rented house are more attractive for customer with } \\
\text { low of purchase power }\end{array}$} \\
\hline & Rented House & High & & \\
\hline \multirow{3}{*}{$\begin{array}{l}\text { Rivalry among } \\
\text { existing competitors }\end{array}$} & Large number of competitors & High & \multirow{3}{*}{\multicolumn{2}{|c|}{$\begin{array}{l}\text { Because there are large number of competitors and the property industry } \\
\text { growth are growing more slower than other basic industry due to high } \\
\text { competition }\end{array}$}} \\
\hline & Slowed industry growth & High & & \\
\hline & High exit barrier & High & & \\
\hline \multicolumn{5}{|c|}{$\begin{array}{c}\text { TABLE } 4 . \\
\text { TABLE OF COMPETITOR ANALYSIS } \\
\end{array}$} \\
\hline Marketing mix & Jombang Citra Raya & \multicolumn{2}{|c|}{ Emerald Garden Jombang } & Hanief Islamic Residence \\
\hline Product & $\begin{array}{l}\text { House with modern minimalism } \\
\text { style consist only } 1 \text { storey houses }\end{array}$ & \multicolumn{2}{|c|}{$\begin{array}{l}\text { House with modern minimalism style consists } \\
\text { with } 1 \text { storey and } 2 \text { storey houses }\end{array}$} & $\begin{array}{l}\text { House with Islamic theme and modern style } \\
\text { consists with } 1 \text { storey and } 2 \text { storey houses }\end{array}$ \\
\hline Place & Jl. M. Yamin Ds. Pandanwangi & \multicolumn{2}{|c|}{ Jl. Nur Cholis Majid } & Jl.Raya Pandanwangi \\
\hline Price & Rp. 234.500.000-544.800.000 & \multicolumn{2}{|c|}{ Rp.275.000.000-Rp.600.000.000 } & Rp.189.000.000-Rp.550.000.000 \\
\hline Promotion & banner, printed media advertising & \multicolumn{2}{|c|}{$\begin{array}{l}\text { Community Approach, Internet marketing, } \\
\text { banner and media advertising, property broker }\end{array}$} & $\begin{array}{l}\text { Internet marketing, banner and media } \\
\text { marketing, property broker }\end{array}$ \\
\hline
\end{tabular}

\section{Internal Interview : In-Depth Interview}

The in-depth interview process was conducted to understand the condition of the company in carrying out its business strategy. In the conclusion from CEO statement, it can be concluded that the question about the condition of the company from the directors' point of view said that there was a problem in house sales from month to month and how much the sales was inappropriate for this company to maintain cashflow and profits so that the company. Second, the results of interviews with marketing admin PT. Sedulur Guyub Rukun, it can be concluded that the statement is same with the CEO there is indeed a decline in sales that involves the loss of the company and the company has now stepped up to do new model techniques that can improve the performance of home sales. And it is expected that this company's marketing 
admin can be offered new marketing communication as a new marketing plan.

\section{External Analysis: Five Porter's Forces \& Competitor analysis}

This section will explain about the competitiveness in property industry, PT. Sedulur Guyub Rukun make a table about the competitiveness of the company in the market (see Table 3).

\section{E. External Analysis: Competitor Analysis}

Based on the internal analysis of marketing mix (4P). PT. Sedulur Guyub Rukun need to compare Jombang Citra Raya with other competitor to know the existing competition that happens in Jombang. the company choose the Emerald Garden Jombang due to the similarity of the product segment and Hanief Islamic Residence due to location are very close to Jombang Citra Raya by location (see Table 4).

\section{F. Questionnaire result and analysis}

From previous analysis on the five Porter's Force and Competitor analysis mentioned that this industry sector has high competition on the product and brand and the author urges to find other factor that drives the customer on purchase decision The author has conducted a survey in the form of a questionnaire to prospective customers to be able to understand what determines the customer in choosing a house. The questionnaire will refer to questions about the factor that influenced the buyer's decision to buy a house, the authors namely product, places, price and environment and the continued to buyer's decision conclusion. From the results of this questionnaire, it can be understood which part of the factor that most influenced the buyer's decisions. Then the results of this questionnaire can refer to conducting for marketing communication strategy of PT. Sedulur Guyub Rukun. The sampling method used is the purposive sampling method. The target respondent is the population of Surabaya and Jombang. This Research needs a 100 respondent to gain the right proportions to achieve the right answer on the questionnaire. Table 5 is the result of multiple linear regression analyses and questionnaire questions about the factor that most influenced buyer's decision on buying a house based on the result of the total score and index score on the questionnaire and refer on the multiple linear regression shows the order of most significant point. From the multiple linear regression results, based on SPSS calculation it has a constant number 1,088. The regression coefficient value (B) represents the significant number that drives the customer significant factor on purchase decision based on multiple linear regression analysis, it mentioned the regression coefficient value (B) of Prices is 0,057 , Places is 0,157 , Products 0,362 and Environment is 0,248. From the value, it can know that the Price factor $(0,057)$ is the least significant to influence the purchase decision and the Product factor $(0,248)$ is the most significant to influence the purchase decision.

TABLE 5 .

TABLE OF MULTIPLE LINEAR REGRESSION RESULT

\begin{tabular}{ccc}
\hline \hline & \multicolumn{2}{c}{ Unstandardized Coefficients } \\
\cline { 2 - 3 } & $\mathrm{B}$ & Std. Error \\
\hline (Constant) & 1,088 & 0,333 \\
Prices & 0,057 & 0,044 \\
Places & 0,157 & 0,063 \\
Products & 0,362 & 0,098 \\
Environment & 0,248 & 0,098 \\
\hline \hline
\end{tabular}

TABLE 6.

TABLE SUMMARY OF THE MOST SIGNIFICANT FACTOR BASED ON MULTIPLE LINEAR REGRESSION

\begin{tabular}{llll}
\hline \hline No. & Factor & \multicolumn{1}{c}{$\begin{array}{c}\text { The most significant } \\
\text { Point }\end{array}$} & $\begin{array}{c}\text { Multiple Linear } \\
\text { Regression result }\end{array}$ \\
\hline 1 & Price & $\begin{array}{l}\text { the price of the house } \\
\text { according to the quality } \\
\text { of the building } \\
\text { proximity of the location } \\
\text { to city public facilities }\end{array}$ & $4^{\text {th }}$ most significant \\
3 & Place & $3^{\text {rd }}$ most significant \\
& Environment & $\begin{array}{l}\text { Good water drainage } \\
\text { conditions in residence } \\
\text { Good Sanitation and } \\
\text { Electricity in the House }\end{array}$ & $2^{\text {nd }}$ most significant \\
\hline \hline
\end{tabular}

Refer from Table 6, these significant points must be important points for elements in the content marketing strategy for PT. Sedulur Guyub Rukun. Marketing communication must be formed to be able to deliver the values contained in PT. Sedulur Guyub Rukun. The discussion of strategy to deliver information about company values will be discussed in business solution in conclusion section. To know the best communication media, the research use the results of the questionnaire regarding advertising or communication media that can be accepted by consumers, from the answers from 100 people about the advertising or communication media that is most acceptable to consumers in buying a house, this answer will be use for proposed marketing communication as the business solution. Table 7 that shows the communication media the most accepted by the respondent.

Refer from the table, communication media by offline advertising are most acceptable and most convincing for the customer to buy a house. So, offline advertising will be chosen for the advertising media for PT. Sedulur Guyub Rukun. 
TABLE 7.

ACCEPTED COMMUNICATION MEDIA BY RESPONDENT

\begin{tabular}{lllll}
\hline \hline & Question & $\begin{array}{c}\text { Answer Amount (total } \\
100 \text { respondents) }\end{array}$ & Conclusion \\
\cline { 2 - 4 } & Yes & No & \\
\hline $\begin{array}{l}\text { Would you prefer to buy a house from online } \\
\text { promotion? }\end{array}$ & 48 & 52 & $\begin{array}{l}\text { From the } 100 \text { respondents, 52 respondent answer "no", online } \\
\text { communication media are not able to convince customers to buy } \\
\text { house }\end{array}$ \\
$\begin{array}{l}\text { Would you prefer to buy a house from offline } \\
\text { advertising (billboards, brochure etc.) }\end{array}$ & 55 & 45 & $\begin{array}{l}\text { From the } 100 \text { respondents, 55 respondent answer "yes". Offline } \\
\text { communication media are able to convince customer to buy house }\end{array}$ \\
$\begin{array}{l}\text { Would you prefer to buy a house from property } \\
\text { broker/agent }\end{array}$ & 44 & 56 & $\begin{array}{l}\text { From the 100 respondents, 56 respondent answer "no", advertising } \\
\text { media through direct marketing(salesman, broker)are not able to } \\
\text { convince customers to buy house }\end{array}$ \\
\hline \hline
\end{tabular}

TABLE 8.

MARKETING COMMUNICATION TOOLS, CHANNEL AND STRATEGY

\begin{tabular}{|c|c|c|c|}
\hline Marketing communication tools & Marketing Channel & Objectives & Strategy \\
\hline \multirow[t]{2}{*}{ Advertising } & Billboards & Brand Awareness & Placed on the strategic place in Jombang \\
\hline & Brochure and Pamphlet & $\begin{array}{l}\text { Brand Awareness and brand } \\
\text { purchase intention }\end{array}$ & $\begin{array}{l}\text { Placed in the mall, supermarket and public } \\
\text { places. }\end{array}$ \\
\hline \multirow[t]{2}{*}{ Public relations \& Publicity } & $\begin{array}{l}\text { Join on the property } \\
\text { exhibition }\end{array}$ & $\begin{array}{l}\text { Brand Awareness \& Brand } \\
\text { Purchase Intention }\end{array}$ & Join property developer exhibition in east java \\
\hline & $\begin{array}{l}\text { Publicity with local news } \\
\text { media }\end{array}$ & Brand Awareness & $\begin{array}{l}\text { Make publicity and review by property expert in } \\
\text { local news media. }\end{array}$ \\
\hline \multirow[t]{2}{*}{ Sales Promotion } & $\begin{array}{l}\text { Prize Incentive for Lucky } \\
\text { customer }\end{array}$ & Brand Purchase Intention & Umrah Prize for 2 lucky customers \\
\hline & $\begin{array}{l}\text { Prize Incentive for } \\
\text { Specific customer }\end{array}$ & Brand Purchase Intention & $\begin{array}{l}\text { Direct prize for customer with purchase of } \\
\text { minimum } 450 \text { Million }\end{array}$ \\
\hline
\end{tabular}

TABLE 9

SCHEDULE Plan FOR MARKETING COMMUNICATION ACTIVITIES

\begin{tabular}{lllllllllllll}
\hline \hline Action Plan & Jan & Feb & Mar & Apr & May & Jun & Jul & Agt & Sep & Okt & Nov & Des \\
\hline Billboards advertising & & & & & & & & & & & \\
Brochure, Pamphlet advertising & & & & & & & & & & \\
Surabaya Property Expo & & & & & & & & & & \\
News and Reviews Publicity & & & & & & & & & & \\
Prize Incentive for Lucky customers & & & & & & & & & & \\
Prize Incentives fee for Specific customers & & & & & & & & & & \\
\hline \hline
\end{tabular}

\section{CONCLUSION}

\section{A. Integrated Marketing Communication Media}

This chapter will propose a new business strategy for PT. Sedulur Guyub Rukun to increase sales of the products and brand awareness of the company based on the external and internal analysis result. The solution for business issues that are used to develop PT. Sedulur Guyub is an integrated marketing communication (IMC). This research examines the most appropriate marketing communication strategy and the analysis of the steps that must be taken to build appropriate marketing communication to reach the widest range of customers, efficient and effective communication strategy.
Based on the Five Porter's Forces, competitor analysis and interview results show the high competition between property developers and the problem that occurs in the company. Therefore, the author give the best recommendation for PT. Sedulur Guyub Rukun to find the right strategy to deliver the information about the products that able to reach on the target market in the most effective way. To formulate the right strategy, questionnaire result analysis is needed to find the most significant point that triggers the buyer's decision on customers and STP analysis are needed to find the right target market.

The formulation of IMC is to approach the target audience with the non-personal channel, for example, Advertising, Public relations, and Publicity and Sales Promotions. Based on the key characteristic of marketing communication tools, non-personal communication tends 
to be more able to reach a large audience and more able to get the brand credibility by target audiences and also these communication tools have the ability to target a particular audience with large audience. All the marketing communication for PT. Sedulur Guyub Rukun should be more focused on to build brand awareness and able to increase the buyer's decision to buy the company products by focusing on advertising, public relations and publicity and sales promotion marketing communication. Each of the strategy proposed is labeled based on its objectives. Table 8 , is the marketing communication tools and channels used for PT. Sedulur Guyub Rukun as the IMC (Integrated Marketing Communication).

\section{B. Schedule Plan for Integrated marketing communication media}

The company urge to solve the problem by making an integrated marketing communication (IMC) strategy to increase brand awareness and brand purchase intention to the customers. the company hopes the result of new marketing communication can increase the sales of products. There are several marketing communications to be planned to gain more sales on the product and brand awareness. There is 3 media communication as a marketing communication media for PT. Sedulur Guyub Rukun: advertising, public relations \& publicity and sales promotion. To support and manage marketing communication media, the company makes a schedule plan for marketing activities and set risk management when the company needs to evaluate the entire strategy. All of the marketing communication activities will start at the beginning of 2020 .

The following paragraph is the explanation of the integrated marketing communication media schedule plan of PT. Sedulur Guyub Rukun:

1. Printed Advertising use brochure, billboard, $x$-banner to advertising the company's products and brands and placed in a strategic area in Jombang, the billboard used for one year in public place promotion area and brochure and pamphlet used for July 2020-February 2021

2. Public relations and Publicity communication tools for communicating about company brand value to reach brand awareness. The activities will be held for only 1 month for public relations as following the expo schedule and for news and reviews in the publicity media will be held on July 2020-February 2021.

3. Prize incentive for lucky customers and the direct prize for a specific customer, this prize lottery will choose 2 winners each period of the promotion. The prize is an
Umrah Tour and a direct prize for a specific customer with a purchase above 450 million. The schedule of prize incentive will be held in the low season of sales (between March-June 2020).

\section{Budget Allocation for IMC Strategy}

After determined time schedule of marketing communication strategy, the next step is arranging the budget allocation for IMC Strategy, from the time schedule of marketing strategy plan, the proposed budget plan based on the marketing strategy plan for 12 months.

TABLE 10.

TOTAL PROPOSED BUDGET FOR IMC

\begin{tabular}{ll}
\hline \multicolumn{1}{c}{ Action Plan } & \multicolumn{1}{c}{ Budget } \\
\hline Brochure & Rp. 140.000 .000 \\
Pamphlet & \\
Billboards & \\
Public relations & Rp. 50.000 .000 \\
News Publicity & Rp. 30.000 .000 \\
Prize Incentive & Rp. 220.000 .000 \\
Total & Rp. 440.000 .000 \\
\hline \hline
\end{tabular}

From the table above explains the purposed budget of PT. Sedulur Guyub Rukun IMC that must be provided for marketing activities. From the budgeting plan above, the largest budget allocation is the Prize incentive marketing communication strategy. This is because the price of Umrah tour is about Rp.30.000.000 per person and the company provides 2 Umrah Package per year and direct prize budgeting for 20 selected customers is Rp.180.000.000 for a year. Budget allocation is reevaluated every 6 months for the Marketing communication risk management, with the proper risk management PT. Sedulur Guyub Rukun to manage the uncertainty that influences the achievement of IMC strategy objectives.

\section{REFERENCES}

Badan Pusat Statistik (BPS), Produk Domestik Bruto Triwulanan. Jakarta: Badan Pusat Statistik (BPS), 2018.

[2] Kemenkeu Indonesia, "Data Backlog Kepemilikan Rumah." [Online]. Available: http://ppdpp.id/data-backlog. [Accessed: 13-Mar-2019].

[3] J. Chappelow, "Porter's 5 Forces Definition," Investopedia, $2019 . \quad$ [Online]. Available: https://www.investopedia.com/terms/p/porter.asp. [Accessed: 11-Mar-2019].

[4] M. Porter, The Five Competitive Forces that Shape Strategy. Tampa, Florida: Harvard Business Review, 2008.

[5] Kotler and Amstrong, "Principles of Marketing," 2010. 